\title{
THE USE OF MIND MAPPING AND FLOW CHARTING IN TEACHING ENGLISH WRITING SKILL OF INTROVERTED STUDENTS
}

\author{
Daniar Sofeny; Irmayani \\ daniarsofeny@unisda.ac.id; irmayani@unisda.ac.id \\ Pendidikan Bahasa Inggris, FKIP, Universitas Islam Darul ‘Ulum
}

\begin{abstract}
Introverted student is a type of student who has a personality related to the world in his own mind. Based on some researches results, they showed that the type of introverted students is getting lower in achievement compared to the extroverted type. For this reason, the researchers tried to apply the techniques in order to improve the introverted students' achievement in learning English. The researchers focused on the writing skill. So, the writing techniques, namely Mind Mapping and Flow Charting are used in this research to improve their writing skill. This study was aimed to know the effectiveness of using Mind Mapping in teaching English writing skill of introverted Students, to know the effectiveness of using Flow Charting in teaching English writing skill of introverted Students, and to determine the better technique between Mind Mapping and Flow Charting in teaching English Writing Skill of Introverted Students. The research technique used was descriptive comparative with a quantitative approach. The results of this study indicated that both techniques are equally effective. The results of the average writing test for the use of Mind Mapping techniques is 56.5, while for the use of Flow Charting techniques is 49.6. From the results of the average score, it can be concluded that flow charting techniques are more effectively used to improve the students writing skills with introverted types.
\end{abstract}

Keywords: Mind Mapping, Flow Charting, Introverted Students

\section{INTRODUCTION}

Writing is one of the most complex skills in English so that it is perceived as the most realistic skill. That is because the errors that occur can be seen easily from the writing produced. (Heaton, 2008, p.141). That's why some innovations are needed in improving the students' writing skills. Especially for the students majoring in English education, they do need the writing skill because in most of their final assignment are in writing form. Moreover, in the final semester they have to create the final course namely thesis. It needs the students ability in writing much. But, based on the result of interview with some students, they said that writing is the most difficult skill to master because they need master other abilities also like vocabulary, grammar, genre of the text, etc. They also said that every mistakes which is made will be more easily known than another skill like speaking, reading, listening.
Related to this, several studies have been carried out with the aim of improving writing skills, one of which is the research conducted by Daniar Sofeny in 2014 under the title The Effectiveness of Discovery Learning in Improving English Writing Skills of Extroverted and Introverted students. In her research, she used quantitative research using an experimental factorial design. The results of her research show that Discovery Learning technique is more effective to be used to improve writing skills of extroverted students compared to students with introverted types. From this research, researchers are interested in studying more about techniques for improving English writing skills of students with introverted types because they seems getting lower in achievement than extroverted students. In fact, nowadays in some classes we found many students are categorized in introvert. 
Many techniques can be used to improve the writing skill, such as the two techniques that researchers use in this study, namely Mind Mapping and Flow Charting. The first technique namely Mind Mapping has been used in the research conducted by Adriati (2013) with the research title is "The use of clustering mapping in teaching writing narrative text". She uses quasi experimental research techniques aimed at 60 high school students in 10th grade. Her research results show that clustering technique effective for use in teaching writing narrative text. The second technique namely Flow Charting also has been used in the research conducted by Sawitri, et al. (2014) with the title "Improving the Eleventh Grade Students' Ability in Writing Simple Cause Effects Sentences through Flow Chart. The research used true experimental research design with the result that Flow chart technique is effective to improve the ability of the eleventh grade students in writing simple cause and effect sentences.

How to use the Mind Mapping technique begins by writing a word as a theme then circled. After that write down the phrase words or phrases related to the theme then circled. The phrase or phrase that has been circled is then linked to the line with the theme. And the last step is choosing which cluster to choose to develop into a writing. While for Flow Charting technique the steps are as follows first determine the chosen theme, then from the theme are grouped into two groups such as cause and effect. Next, just write the idea according to the chart that has been determined.

From the explanation of these two techniques, researchers are interested in applying these two techniques, namely Mind Mapping and Flow Charting to improve English writing skills for students with introverted types.

\section{METHOD}

The method used in this study is descriptive comparative method with a quantitative approach. The product result of students writing will be used to analyze the data. Furthermore, the data was analyzed using analysis of variance (ANOVA). ANOVA is the difference between the mean scores of two or more groups on a dependent variable is statistically significant. When the groups have been classified in several independent variables, the procedure can be used to determine each factor and the interactions between the factors have a statistically significant effect on the dependent variable (Gallet et al., 2007: 419). To test the hypotheses, a two-way analysis of variance with F-test at the 5\% (0.05) level of significance was used. ANOVA Two-way requires two basic things including normal distribution score for each sell and homogeneity of the score variation (Irianto,1989). It is the answer to the problem that is claimed, which is the most effective technique of writing English skills. It is used to answer which is one of the better features between Mind Mapping and Flow Charting.

\section{DISCUSSION}

This research was conducted in 4 meetings. The first meeting was used for giving the psychological types test using Myers Briggs Type Indicator (MBTI) personality inventory which is firmly grounded in Carl Gustav Jung's theory of psychological type is a way of describing and explaining certain consistent differences in the ways that normal people use their mind. In this meeting also given pre test of the students' writing skill before using both techniques. The second was used as a time for data collection using the Mind Mapping technique. The third meeting 
was used as a time for data collection using Flow Charting techniques. The last meeting is used as time for doing interview. Writing test assessment uses Brown (2007) assessment model with Content (C) Organization (O), Sintax (S),
Vocabuaries (V), and Mechanic (M) components. The data obtained are as follows:

Table 1.Writing Test Results Using Mind Mapping Technique

\begin{tabular}{|c|c|c|c|c|c|c|c|}
\hline \multirow{2}{*}{ No } & \multirow{2}{*}{ Name } & \multicolumn{5}{|c|}{ Components } & \multirow{2}{*}{ Total } \\
\hline & & C & O & $\mathbf{S}$ & $\mathbf{V}$ & $\mathbf{M}$ & \\
\hline 1 & AS & 15 & 10 & 5 & 5 & 5 & 40 \\
\hline 2 & YF & 20 & 15 & 8 & 10 & 10 & 63 \\
\hline 3 & FK & 22 & 15 & 10 & 10 & 10 & 67 \\
\hline 4 & NA & 22 & 15 & 10 & 10 & 10 & 67 \\
\hline 5 & YES & 22 & 18 & 10 & 10 & 10 & 70 \\
\hline 6 & $\mathrm{DF}$ & 15 & 10 & 5 & 7 & 5 & 42 \\
\hline 7 & AA & 22 & 18 & 11 & 11 & 11 & 73 \\
\hline 8 & SL & 22 & 18 & 11 & 11 & 11 & 73 \\
\hline 9 & DN & 15 & 15 & 8 & 10 & 11 & 59 \\
\hline 10 & HNHS & 10 & 10 & 10 & 10 & 10 & 50 \\
\hline 11 & DL & 15 & 10 & 8 & 7 & 10 & 50 \\
\hline 12 & INS & 15 & 10 & 8 & 10 & 10 & 53 \\
\hline 13 & W & 10 & 15 & 10 & 10 & 10 & 55 \\
\hline 14 & GP & 15 & 10 & 8 & 10 & 11 & 54 \\
\hline 15 & $\mathrm{~S}$ & 15 & 10 & 10 & 10 & 10 & 55 \\
\hline 16 & ARW & 10 & 10 & 8 & 7 & 10 & 45 \\
\hline 17 & $\mathrm{NF}$ & 15 & 15 & 8 & 10 & 10 & 58 \\
\hline 18 & ANA & 15 & 10 & 10 & 10 & 10 & 55 \\
\hline 19 & NR & 10 & 10 & 8 & 10 & 11 & 49 \\
\hline 20 & HPN & 15 & 10 & 10 & 10 & 11 & 56 \\
\hline 21 & QA & 15 & 15 & 8 & 7 & 10 & 55 \\
\hline \multirow[t]{3}{*}{22} & NR & 15 & 15 & 8 & 10 & 10 & 58 \\
\hline & Jumlah & 350 & 284 & 192 & 205 & 216 & 1247 \\
\hline & Rata-rata & 15,9 & 12,9 & 8,7 & 9,3 & 9,8 & 56,6 \\
\hline
\end{tabular}

Based on the table 1, it can be seen that the average score of the results of the test writing of 22 students using the Mind Mapping technique is 56.5. The data is also further tested by testing the normality calculated using spss version 20 which shows that the data is in normal distribution.

Table 2.Writing Test Results Using Flow Charting Technique

\begin{tabular}{|c|c|c|c|c|c|c|c|}
\hline \multirow{2}{*}{ No. } & \multirow{2}{*}{ Name } & \multicolumn{5}{|c|}{ Components } & \multirow{2}{*}{ Total } \\
\hline & & $\mathbf{C}$ & $\mathbf{O}$ & $\mathbf{S}$ & $\mathbf{V}$ & $\mathbf{M}$ & \\
\hline 1 & AS & 15 & 12 & 10 & 10 & 7 & 54 \\
\hline 2 & YF & 10 & 10 & 5 & 10 & 5 & 40 \\
\hline 3 & FK & 15 & 12 & 8 & 5 & 10 & 50 \\
\hline 4 & NA & 15 & 10 & 10 & 10 & 7 & 52 \\
\hline 5 & YES & 10 & 12 & 5 & 10 & 5 & 42 \\
\hline 6 & DF & 15 & 10 & 8 & 5 & 10 & 48 \\
\hline 7 & $\mathrm{AA}$ & 15 & 12 & 10 & 10 & 7 & 54 \\
\hline 8 & SL & 10 & 10 & 5 & 10 & 5 & 40 \\
\hline 9 & $\mathrm{DN}$ & 15 & 10 & 8 & 5 & 5 & 43 \\
\hline 10 & HNHS & 22 & 17 & 10 & 10 & 10 & 69 \\
\hline 11 & DL & 15 & 10 & 5 & 10 & 7 & 47 \\
\hline 12 & INS & 15 & 10 & 5 & 5 & 5 & 40 \\
\hline 13 & $\mathrm{~W}$ & 10 & 15 & 10 & 10 & 5 & 50 \\
\hline 14 & GP & 22 & 18 & 11 & 11 & 11 & 73 \\
\hline 15 & $\mathrm{~S}$ & 20 & 12 & 10 & 10 & 5 & 57 \\
\hline 16 & ARW & 15 & 12 & 10 & 10 & 7 & 54 \\
\hline 17 & $\mathrm{NF}$ & 10 & 10 & 5 & 10 & 5 & 40 \\
\hline
\end{tabular}




\begin{tabular}{llcccccc}
18 & ANA & 15 & 12 & 8 & 5 & 10 & 50 \\
19 & NR & 15 & 10 & 10 & 10 & 7 & 52 \\
20 & HPN & 10 & 12 & 5 & 10 & 5 & 42 \\
21 & QA & 15 & 10 & 8 & 5 & 10 & 48 \\
22 & NR & 15 & 12 & 10 & 10 & 7 & 54 \\
\hline & \multirow{2}{*}{ Jumlah } & \multirow{2}{*}{$\mathbf{2 5 8}$} & $\mathbf{1 5 8}$ & $\mathbf{1 9 1}$ & $\mathbf{1 5 5}$ & $\mathbf{1 0 9 9}$ \\
\hline & Rata-rata & $\mathbf{1 4 , 5}$ & $\mathbf{1 1 , 7}$ & $\mathbf{7 , 2}$ & $\mathbf{8 , 7}$ & $\mathbf{7 , 0}$ & $\mathbf{4 9 , 6}$ \\
\hline
\end{tabular}

Based on table 2. it can be seen that the average score of the results of the test writing of 22 students using Flow Charting technique is 49.6. The results of the normality test also show that the data is in normal distribution.
The following is a graph that shows the results of test writing from both techniques (Mind Mapping and Flow Charting).

Grafik 1. Grafik perolehan nilai writing test dengan menggunakan teknik Mind Mapping dan Flow Charting

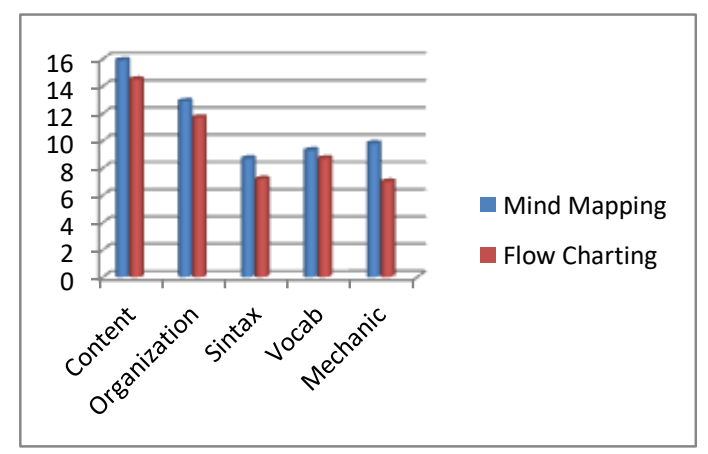

Based on the results of the students' writing scores that have been obtained after using the two writing techniques (Mind Mapping and Flow Charting), the average score is known. For the average score, the use of Mind Mapping technique was 56.5, while the average score of the use of Flow Charting technique was 49.6. It can be concluded that the Mind Mapping technique is better effective to use than Flow Charting.

\section{CONCLUSION}

Based on the results achieved from this study, the researchers can conclude. First, the technique of mind mapping, flow charting are two of the many writing techniques that can be used in improving writing skills. Second, Mind
Mapping is an effective technique used by students because the techniques used are easier to develop ideas based on predetermined themes. Third, Flow Charting is an effective technique used by students but it feels less effective because they encounter some difficulties such as the use of vocabulary and the development of monotonous sentences with only one plot.

Mind Mapping is the better effective technique compared to the Flow Charting in teaching writing skill of introverted students.

\section{Thank-you Note}

Researcher do says thanks to LPPM Unisda Lamongan who has provided funding for this research 
activity. The researcher also expressed his gratitude to the Directorate of Research and Community Service Director General of Research and Development Strengthening the Ministry of Research, Technology and Higher Education for those who have funded this research.

\section{REFERENCES}

Cf. Gabriel Heaton. 2008. Writing and Reading Royal Entertainments. Oxford, Oxford University Press.

Sofeny, Daniar. 2014. The Effectiveness of Discovery Learning in Improving English Writing Skill of Extroverted and Introverted Students.Thesis. Semarang, Unnes Press.

Brown, H. 2007. Principles of Language Learning and Teaching. 4th ed. White Plains,
Sherrill, Addison Wesley Longman.

Adriati, Meliya. 2013. Journal of English and Education. The Use of Clustering Technique in Teaching Writing Narrative Text. 1(2), 39 - 46. From: ejournal.upi.edu/index.php/LE/article/download/582/439.

Sawitri et al. 2014. e-journal of English Language Teaching Society (ELTS) Vol.2 No.1 2014 - ISSN 2331 - 1841. Improving the Eleventh Grade Students Ability in Writing Simple Cause Effect Sentences Through Flow Chart. From:

https://www.researchgate.net/pu blication/304628683_Improving _the_Eleventh_Grade_Students $\% 27$ ability_in_Writing_Simple _Cause_Effect_Sentences_throu gh_Flow_Chart 